\title{
CLINICAL IMPACT OF SENTINEL LYMPH NODE BIOPSY AFTER NEOADJUVANT SYSTEMIC TREATMENT IN LUMINAL B, HER-2 POSITIVE AND TRIPLE-NEGATIVE BREAST CANCER PATIENTS WITH INITIALLY INVOLVED AXILLARY LYMPH NODE(S) Protocol for prospective, non-randomised, observational clinical trial
}

\author{
ANA CAR PETERKO ${ }^{1}$, MANUELA AVIROVIĆ ${ }^{2}$, DIANA MANCE ${ }^{3}$, PETRA VALKOVIĆ ZUJIĆ ${ }^{4}$ \\ INGRID BELAC LOVASIĆ ${ }^{5}$, FRANJO LOVASIĆ ${ }^{1}$
}

${ }^{1}$ Department of General Surgery and Surgical Oncology, Clinical Hospital Center Rijeka, Rijeka, Croatia; ${ }^{2}$ Department of General Pathology and Pathologic Anatomy, University of Rijeka, Faculty of Medicine, Rijeka, Croatia;

${ }^{3}$ Department of Radiology, Clinical Hospital Center Rijeka, Rijeka, Croatia;

${ }^{4}$ Physics Department, University of Rijeka, Rijeka, Croatia;

${ }^{5}$ Department of Radiotherapy and Oncology, Clinical Hospital Center Rijeka, Rijeka, Croatia

\section{Summary}

Background: Upon St. Gallen consensus conference (1) and updated version of NCCN guidelines (2) from 2017, in May 2017 in Clinical Hospital Center Rijeka sentinel lymph node biopsy (SLNB) was introduced in clinical practice for axillary staging of breast cancer patients that achieved complete clinical axillary remission after neoadjuvant systemic oncologic treatment.

This trial aims to evaluate the clinical impact of SLNB performance after neoadjuvant systemic treatment (NAST) in initially node-positive breast cancer patients and to determine the prognostic value of the axillary complete pathological response.

Patients and Methods: Breast cancer patients in clinical stage T1-T3 N0-N2 M0, surgically treated in our institution from September 2018 till May 2022 would be included in this trial and divided into three groups according to protocol. SLNB would be performed in all patients presenting with cN0 stage at the time of surgery, including those patients who shift from cN1-N2 to $\mathrm{cN} 0$ during NAST. All patients involved in this trial would be monitored for five postoperative years in order to determine following parameters: rates of local and regional recurrence, rate of disease progression to M1 stage, regional recurrence-free survival, disease progression-free survival, cancer-related mortality rate, and overall survival.

Results: Results gained from this trial would be compared among groups and with our previous data of patients in equivalent stage treated in period from 2011 till 2014 when all patients were primary surgically treated, therefore axillary lymph node dissection (ALND) was performed for all node-positive patients.

Conclusion: Hopefully, the results of this trial would provide enough evidence that SLNB performance after NAST does not have a negative impact on clinical outcome in breast cancer patients who had reached complete clinical axillary remission. In addition, we would try to determine the prognostic value of the axillary complete pathologic response.

ClinicalTrials.gov: This protocol has been registered at clinicaltrials.gov with ID: NCT03719833

Abbreviations: SLNB=sentinel lymph node biopsy, ALND=axillary lymph node dissection, NAST=neoadjuvant systemic treatment, $\mathrm{US}=$ ultrasound, $\mathrm{MRI}=$ magnetic resonance imaging, $\mathrm{RRR}=$ regional recurrence rate, $\mathrm{RRFS}=$ regional recurrence-free survival, DFS=disease free survival, $C S M R=$ cancer specific mortality rate, $O S=$ overall survival

KEYWORDS: sentinel lymph node biopsy, neoadjuvant therapy, node-positive, complete response, regional recurrence 
UTJECAJ BIOPSIJE SENTINEL LIMFNOG ČVORA NAKON NEOADJUVANTNOG SISTEMSKOG LIJEČENJA NA KLINIČKI ISHOD BOLESNICA OBOLJELIH OD LUMINAL B, HER-2 POZITIVNOG I TROSTRUKO NEGATIVNOG KARCINOMA DOJKE SA INICIJALNO METASTATSKI ZAHVAĆENIM AKSILARNIM LIMFNIM ČVOROVIMA Protokol prospektivnog, nerandomiziranog, opservacijskog kliničkog istraživanja

\section{Sažetak}

Uvod: Temeljem konsenzusa konferencije u St. Gallen-u i revidiranih NCCN-ovih smjernica za liječenje raka dojke iz 2017., u svibnju iste godine u KBC-u Rijeka biopsija sentinel limfnog čvora (SLNB) uvedena je u kliničku praksu kao metoda izbora procjene aksilarnog stadija za bolesnice oboljele od karcinoma dojke sa inicijalno zahvaćenom aksilom, a koje su neoadjuvantnim sistemskim liječenjem (NAST) postigle kompletnu kliničku aksilarnu remisiju.

Kako bi evaluirali utjecaj izvođenja SLNB nakon NAST na ishod liječenja kod spomenute skupine pacijentica i pokušali objektivizirati prognostički značaj kompletnog patološkog aksilarnog odgovora (pCR) osmislili smo protokol prospektivnog opservacijskog kliničkog istraživanja.

Pacijenti i metode: U istraživanje će biti uključene bolesnice oboljele od karcinoma dojke u stadiju T1-T3 N0-N2 M0, kirurški liječene u KBC Rijeka u periodu od rujna 2018. do svibnja 2022. Iste će biti podijeljene u tri grupe u skladu sa definiranim protokolom. SLNB će se učiniti kod svih bolesnica koje se preoperativno prezentiraju u stadiju cN0, uključujući i bolesnice koje su se neoadjuvantnim liječenjem konvertirale iz stadija cN1-N2 u stadij cN0. U petogodišnjem postoperativnom periodu pratit će se pojavnost lokalnog i regionalnog recidiva, progresije bolesti u M1 stadij, smrtnost od karcinoma i sveukupno preživljenje.

Rezultati: Rezultati će se usporedit između skupina definiranih protokolom ovog istraživanja te sa rezultatima skupina bolesnica ekvivalentnog stadija bolesti liječenih u periodu od 2011. do 2014. kada su bolesnice bile primarno kirurški liječene, odnosno kada je svim bolesnicama sa inicijalno pozitivnim aksilarnim limfnim čvorovima standardno učinjena aksilarna disekcija (ALND).

Zaključak: Dobivenim rezultatima želimo potvrditi osnovnu hipotezu ovog istraživanja; da procedura SLNB nakon NAST nema negativan utjecaj na ishod liječenja kod bolesnica sa inicijalno pozitivnom aksilom koje su preoperativnom sistemskom terapijom postigle remisiju bolesti u aksili. Uz navedeno pokušat ćemo odrediti prognostički značaj downstaging-a aksile neoadjuvantnim liječenjem. ClinicalTrial.gov: Protokol istraživanja je registriran i javno dostupan na stranicama www.clinicaltrials.gov (ID:NCT03719833)

KLJUČNE RIJEČI: biopsija sentinel limfnog čvora, neoadjuvantna terapija, pozitivni limfni čvor, kompletni odgovor, regionalni recidiv

\section{BACKGROUND}

\section{Introduction}

Until recently, axillary lymph node dissection was the standard approach in axillary surgery after neoadjuvant treatment of operable breast cancer, due to controversy about the reliability of sentinel lymph node biopsy after primary systemic treatment. Although the initial researches $(3,4,5)$ had a wide range of identification rate (IR) and high false-negative rates (FNR), the following trials (6-15) offered optimization methods resulting with $95 \%$ IR and less than 10\% FNR., which is equal to IR and FNR of SLNB performance for early breast cancer. Therefore, in 2017 a consensus was reached at a conference in St. Gallen (1), and in same time updated version of NCCN guidelines for breast cancer treatment (2) declares the recommendation for SLNB performance after NAST in breast cancer patients presenting with uninvolved axilla at the time of surgery. In May
2017, the practice was accepted in Clinical Hospital Center Rijeka. Current clinical experience and preliminary results of our retrospective analysis have not shown any negative impact on the clinical outcome of these patients. To confirm these observations, we initiated a prospective clinical trial in September 2018.

\section{Hypotheses}

There are two main hypotheses of this trial. First, SLNB does not have a negative impact on clinical outcome in initially node-positive breast cancer patients who achieved clinical axillary remission following NAST and second, lymph node status after NAST is significantly more relevant prognostic factor than nodal status at the time of diagnosis. In addition, we wish to evaluate if identification and biopsy of pre-neoadjuvant positive node(s) significantly increase the reliability of SLNB, to determine the correlations of axillary pathologic complete response and the characteris- 
tics of primary tumor and to evaluate the accuracy of axillary ultrasound (US) and standard breast magnetic resonance imaging (MRI) in axillary reevaluation after NAST.

\section{PATIENTS AND METHODS}

\section{Study design}

The present clinical study is a prospective, observational, non-randomised clinical trial of the overall duration of 8-9 years. In the recruiting phase, that would last for 3-4 years. The investigators would create three predetermined cohorts of breast cancer patients, all eventually submitted to surgery. We will include 50 patients in each arm, based on the available study and our patient volume. We will try to include other centers in Croatia soon. First results and conclusions (regarding our secondary endpoints) could be reached at the end of this phase. In the second phase, follow up period of five postoperative years, all patients involved in this trial would be periodically monitored for, earlier mentioned primary endpoints of this trial.

\section{Inclusion and exclusion criteria}

All female breast cancer patients from 18 to 80 years old, presenting in clinical stage T1-T3 N0N2 M0, surgically treated in Clinical Hospital Center Rijeka in the period from September 2018 till May 2022, would be involved in this trial. However, patients should have biopsy-proven ductal breast cancer, Luminal B, HER-2 positive or triple-negative subtype and those patients with nodal disease should have cytological proof of metastatic disease and marked positive node(s) with titanium clip at the onset of NAST. Furthermore, patients in T2-T3 and/or N1-N2 stage must be eligible for systemic oncological treatment, accepting to undergo it and complete it. All patients involved in the trial must understand, accept and signed the approved consent form.

Patients with bilateral disease, unilateral recurrence, previous axillary surgery or axillary radiotherapy, treated or in treatment for another malignant disease and patients without complete documentation required for this study would be excluded.

\section{Groups}

Based on US and/or MRI assessment of primary tumor dimensions, pathological report of core needle biopsy, US evaluation of axillary lymph node status and cytological proof of involved node(s), patients would be allocated in following groups; group 1 (T1 N0 M0), group 2 (T2-T3 N0N2 M0) and group 3 (T1-T3 N1-N2 M0).

\section{Protocol}

All patients would be subjected to ultrasound (US) assessment of primary tumor dimensions, US-guided core needle biopsy of the primary tumor and the axillary US. For all suspicious nodes, US-guided fine-needle aspiration cytology would be made. Patients in T1N0 stage would be assigned to group 1 and subdue to surgery (lumpectomy and SLNB), following by adjuvant systemic oncological treatment. For stage T2-T3 patients breast MRI would be done and titanium clip placement at the primary tumor site. For stage N1 patients, titanium clip would be placed in cytology proven metastatic node(s). According to $\mathrm{N}$ status, patients would be allocated to group 2 or 3 and subdue to neoadjuvant systemic treatment lasting 24 weeks, following by surgery and adjuvant oncological treatment. At the end of NAST, all patients would be submitted to breast MRI for evaluation of the clinical response of the primary tumor to NAST and those with initially involved nodes would be subdued to axillary reevaluation by US.

All MRI exams would be performed with a 1,5T unit (MAGNETOM Avanto; Siemens Medical Solutions, Erlangen, Germany) with a dedicated bilateral eight-channel breast coil. The axillary ultrasound would be performed with a high-frequency linear array transducer up to $15 \mathrm{MHz}$ on LOGIQ S8® (General Electric Medical Systems, Milwaukee, USA). Lymph node(s) would be categorized as suspicious if they exhibited one or more of the following characteristics: loss of central fatty hilum/thinning of hilum, eccentric thickening of the cortex, heterogenous echotexture, illdefined capsular margins and irregular or round shape.

SLNB would be done for all patients presenting preoperative with cN0 stage, and for group 3 patients, titanium marked node(s) would be surgically removed along with SLNB procedure. 
Background of sentinel lymph node(s) detection would be lymphoscintigraphy with $99 \mathrm{mTc}-$ labeled nano colloid (Nanocoll). On an operating day, radiocolloid would be injected intradermally in the breast, and preoperative plane scintigraphy would be done after 30 minutes. Intraoperatively hand-held gamma detecting probe (Neoprobe ${ }^{\circledR}$ Gamma Detecting System) would be used in order to detect sentinel node(s).

All biopsied nodes would be examined intraoperatively by imprint cytology and on frozen sections by HE staining. The final pathological report would be made on paraffin-embedded sections by HE staining and panCK. In the pathologic report, positive node after NAST would be considered any node that contains residual tumor regardless of the size of the tumor. For the presence of any residual nodal disease after NAST, ALND would be performed.

The pathological stage would be defined according to the current TNM classification by the AJCC Cancer Staging Manual.

In postoperative five years follow up period, all patients would be monitored for the appearance of local and regional recurrence, progression of the disease to M1 stage and cancer-related death.

\section{RESULTS}

\section{Outcome measures}

Primary endpoints are: rates of local and regional recurrence, a progression of the disease to M1 stage rate, regional recurrence-free survival (RRFS), disease progression-free survival (DPFS), cancer-related mortality rate and overall survival (OS).

Secondary endpoints are: correspondence rate between metastatic marked node and nonsentinel nodes, correlations of axillary complete pathologic remission and characteristics of primary tumor (subtype, grade, size, proliferation index, presence of lymphovascular invasion and pathologic complete response of primary tumor), sensitivity, specificity, positive predictive value and negative predictive value of axillary US and standard breast MRI in axillary assessment after NAST.

All relevant data would be collected on patients checklists and summarized in a table at the end of this trial for statistical analysis.

\section{Statistical analysis}

The Statistica 13.0 commercial software (Statsoft Inc., Tulsa, OK, USA) and the statistical significance level at $p<0.05$ would be used for statistical calculations. To test relationships between categorical variables, we would use either the Chi-square test, Fisher exact test, or the McNemar test. Spearman's correlation, as well as logistic regression, would be used for testing the associations between axillary pathological complete remission and biological characteristics of the primary tumor.

\section{DISCUSSION}

The impact of sentinel lymph node biopsy procedure after neoadjuvant systemic therapy in initially node involved breast cancer patients who achieved complete clinical axillary remission needs assessment. in this trial we would compare regional recurrence rate (RRR) and regional recurrence-free survival (RRFS) of group 3 to RRR and RRFS of group 1 and group 2 and to RRR and RRFS from our former data (group of patients in equivalent initial stage treated without NAST, therefore ALND was performed for all node-positive patients). Based on our current clinical experience and the preliminary results of our retrospective analysis we expect that the RRR and RRFS of group 3 patients would not be significantly worse than in the group of patients in whom ALND was performed, moreover, we expect them to be even better (i.e. lower RRR and higher RRFS). Also, we want to determine if these results of the third group differ significantly from the results of the first and second group of patients.

In order to try to objectively estimate prognostic value of axillary pathologic complete response, we will compare disease-free survival (DFS), cancer-specific mortality rate (CSMR) and overall survival (OS) of sentinel node-negative patients from group 3 to DFS, CSMR and OS of nodepositive patients from group 3 and to group of patients of equivalent initial nodal status treated in period from 2011 till 2014 (i.e. without NAST and with ALND).

To determine the significance of node marking procedure for the accuracy of SLNB after NAST in node-positive patients, we would try to determine the correspondence rate between a 
marked node(s) and metastatic non-sentinel node(s). According to our clinical experience, we believe that with the possibility of detecting and removing at least three sentinel nodes, this method might be safely omitted.

Based on sensitivity, specificity, negative predictive value and positive predictive value, and relative to breast cancer subtypes, we would try to evaluate the accuracy of the axillary US and standard breast MRI in axillary lymph node reevaluation at the end of neoadjuvant treatment. Thereby we would estimate the possibility of undertreatment and overtreatment with surgeons' decision on the extent of axillary surgical procedure guided by radiological indications.

We would determine the axillary pathologic complete remission rate in correlation with tumor subtypes to assess whether involved axillary lymph node(s) at presentation is an absolute indication for NAST, regardless pathological characteristic of the primary tumor and the size of the primary tumor.

\section{CONCLUSIONS}

Recent studies (6-14) have shown that SLNB is an acceptable alternative of ALND for axillary staging after NAST in initially node-positive breast cancer patients who shift to node-negative, with IR of $95 \%$ and less than $10 \%$ of FNR. Our clinical experience and preliminary results of our retrospective analysis, as well as the results from an Italian retrospective analysis (16), suggest that SLNB performance following NAST does not have a negative impact on clinical outcome in initially node-positive breast cancer patients. Moreover, we strongly believe that this subgroup of patients from our third cohort are exactly those patients with the best prognosis.

We hope that this clinical trial would provide enough evidence for the above statements, thereby contribute to the acceptance of SLNB performance after NAST and enable the avoidance of all unnecessary ALND.

Ethical issues This clinical trial is approved by Ethics Committee of Clinical Hospital Center Rijeka in September 2018.

Registration This clinical trial is registered and publicly available on clinicaltrials.gov, ID: NCT03719833
Conflict of interest: Authors declare no conflict of interest.

\section{REFERENCES}

1. Lurigliano G, Burstein HJ, Winer EP. et al. De-escalating and escalating treatment for early-stage breast cancer: The St. Gallen International Consensus Conference on Primary Therapy of Early Breast Cancer. Annals of Oncology. 2017;28:1700-1712.

2. National Comprehensive Cancer Network, Clinical Practice guidelines in oncology, Breast Cancer, Version 4.2017. At: www.nccn.org. Accessed on $7^{\text {th }}$ February 2018.

3. Takahashi M, Jinno H, Hayashida T, Sakata M, Asakura K, Kitagawa Y. Correlation between clinical nodal status and sentinel lymph node biopsy false-negative rate after neoadjuvant chemotherapy. World J Surg. 2012;36(12):2847-2852.

4. Alvarado R, Yi M, Le-Petross $\mathrm{H}$ et al. The role for sentinel lymph node dissection after neoadjuvant chemotherapy in patients who present with node-positive breast cancer. Ann Surg Oncol. 2012;19(10):3177-3184.

5. Kuehn T, Bauerfeind I, Fehm T. et al. Sentinel-lymphnode biopsy in patients with breast cancer before and after neoadjuvant chemotherapy (SENTINA): a prospective, multicentric cohort study. Lancet Oncol. 2013;14(7):609-618.

6. Newman EA, Sabel MS, Nees AV et al. Sentinel lymph node biopsy performed after neoadjuvant chemotherapy is accurate in patients with documented nodepositive breast cancer at presentation. Ann Surg Oncol. 2007;14(10):2946-2952.

7. Canavese G, Dozin B, Vecchio C et al. Accuracy of sentinel lymph node biopsy after neo-adjuvant chemotherapy in patients with locally advanced breast cancer and clinically positive axillary nodes. Eur J Surg Oncol. 2011;37(8):688-694.

8. Hunt KK, Yi M, Mittendorf EA. et al. Sentinel lymph node surgery after neoadjuvant chemotherapy is accurate and reduces the need for axillary dissection in breast cancer patients. Ann Surg. 2009;250(4):558-566.

9. Xing Y, Foy M, Cox DD, Kuerer HM, Hunt KK, Cormier JN. Meta-analysis of sentinel lymph node biopsy after preoperative chemotherapy in patients with breast cancer. Br J Surg. 2006;93(5):539-546.

10. Kelly AM, Dwamena B, Cronin P, Carlos RC. Breast cancer sentinel node identification and classification after neoadjuvant chemotherapy - systematic review and meta-analysis. Acad Radiol. 2009;16(5):551-563.

11. Corso G, Grana CM, Gilardi L. et al. Feasibility of lymphoscintigraphy for sentinel node identification after neo-adjuvant therapy. Ann Ital Chir. 2017;88:201-205.

12. Boughey JC, Suman VJ, Mittendorf EA. et al. Sentinel lymph node surgery after neoadjuvant chemotherapy in patients with node-positive breast cancer: the 
ACOSOG Z1071 (Alliance) clinical trial. JAMA. 2013; 310(14):1455-1461.

13. Boileau JF, Poirier B, Basik M. et al. Sentinel node biopsy after neoadjuvant chemotherapy in biopsy-proven node-positive breast cancer: the SN FNAC study. J Clin Oncol. 2015;33(3):258-264.

14. Boughey JC, Ballman KV, Hunt KK. et al. Axillary ultrasound after neoadjuvant chemotherapy and its impact on sentinel lymph node surgery: results from the American College of Surgeons Oncology Group Z1071 Trial (Alliance). J Clin Oncol. 2015; 33(30):3386-3393.

15. Guteša I, Potesak I, Pavičić I, Tometić G, Kirac I, Penavić I et al. Sentimag sentinel lymph node biopsy in breast conservative surgery- preliminary results. Lib Oncol. 2016;44(2-3):15-19.

16. Galimberti V, Ribeiro Fontana SK, Maisonneuve P et al. Sentinel node biopsy after neoadjuvant treatment in breast cancer: five-year follow-up of patients with clinically node-negative or node-positive disease before treatment. Eur J Surg Oncol. 2016;42(3):361-368.

Corresponding author: Ana Car Peterko, Department of General Surgery and Surgical Oncology, Clinical Hospital Center Rijeka, Krešimirova 42, 51000 Rijeka, Croatia. e-mail:ana.car.peterko@uniri.hr 